\title{
Effect of Chronic Administration of Hydromethanol Leaf Extract of Helianthus annuus on Erythrocytic Profile in Normal Rats
}

\author{
Samuel O. Onoja ${ }^{1, *}$, Samuel C. Udem ${ }^{2}$ and Aruh O. Anaga ${ }^{2}$ \\ ${ }^{1}$ Department of Veterinary Physiology, Pharmacology, Biochemistry and Animal Health and Production, \\ Michael Okpara University of Agriculture, Umudike, Nigeria \\ ${ }^{2}$ Department of Veterinary Physiology and Pharmacology, Faculty of Veterinary Medicine, University of \\ Nigeria, Nsukka, Nigeria
}

\begin{abstract}
Effect of chronic administration of hydromethanol leaf extract of Helianthus annuus on erythrocytic profile in normal rat was investigated. The extract was prepared using cold maceration method and concentrated at $40^{\circ} \mathrm{C}$. It was incorporated in feed at 2.5, 5 and $10 \mathrm{mg}$ per $100 \mathrm{~g}$ feed. Albino rats were randomly assigned to 4 (A - D) groups of 14 rats each. Group A received standard feed while groups B - D received feed incorporated with $H$. annuus at 2.5, 5 and $10 \mathrm{mg} / 10 \mathrm{~g}$ feed, respectively. They were fed $10 \%$ of their body weight daily for 90 consecutive days. Blood samples were collected via retroorbital venous plexus from four rats selected at random from each group without replacement on day 30, 60 and 90 for the determination of erythrocytic profile. There was no significant $(p>0.05)$ change on the erythrocytic profile of the various groups on day 30 and 60 while the packed cell volume and hemoglobin concentration of $H$. annuus treated groups were significantly $(p<0.05)$ lower than group A rats on day 90 . This study suggests that the chronic use of Helianthus annuus for up to 90 days in rat may lead to anemia and should be avoided.
\end{abstract}

Keyword: Helianthus annuus, chronic toxicity, erythrocytic profile, anemia, terpenes.

\section{INTRODUCTION}

Helianthus annuus (sunflower) is relatively a primitive member of the family Asteraceae. It has worldwide distribution and usually found along water ways due to its mode of dispersal. It is used as an ornamental plant and the seed are widely used as sources of vegetable oil while seed meal serve as feedstuff for farm animals [1]. The plant is extensively used in ethnomedical practices of several cultures. Helianthus annuus leaves are used in folkloric medicine as diuretic, antidiabetic, expectorant, gastrointestinal stimulant, antimicrobial, analgesic agents etc [2-4]. Poultice of $H$. annuus leaves is applied on wound, snakebite and swelling [5]. Preliminary phytochemical studies on $H$. annuus have reported the presence of saponins, terpenes, flavonoids, tannins, alkaloids and glycoside [4, 6]. The presence of several essential oil in the leaves of $H$. annuus; $80 \%$ monoterpenes and other sesquiterpenes have been reported [2, 7]. The antispermatogenic [3], analgesic and anti-inflammatory [5], antidiabetic and antioxidant [4], antifertility [8], antidiarrheal and antihistaminic [9], antilithiatic [10] and antimicrobial [6] activities of $H$. annuus have been reported.

Helianthus annuus leaves contain high proportion of saponins and terpenes $[4,6]$ and its consumption for a

\footnotetext{
*Address correspondence to this author at the Department of Veterinary Physiology, Pharmacology, Biochemistry and Animal Health and Production, Michael Okpara University of Agriculture, Umudike, Nigeria;

Tel: +2348030613032; E-mail: samonreal@yahoo.com,

onoja.samuel@mouau.edu.ng, samuelonoja19@yahoo.com
}

long period of time especially in diabetes mellitus management call for concern about its possible erythrocytic toxicity. Saponins causes hemolysis of red blood cell in vivo [11] This study investigated the effects of hydromethanol extract of $H$. annuus on erythrocytic profile in normal rat.

\section{MATERIAL AND METHODS}

\section{Plant Collection and Extract Preparation}

The leaf of Helianthus annuus was collected from the wild in Nsukka, Enugu state, Nigeria and identified by plant taxonomist. The leaves were dried under shed at ambient temperature $\left(25-27^{\circ} \mathrm{C}\right)$. Hydromethanol extract of $H$. annuus was prepared using cold maceration method as described by Onoja and Anaga [4] and was referred to as hydromethanol leaf extract of $H$. annuus (HLEHA).

\section{Animals}

Fifty six (56) female albino Wistar rats were used for the study. They were housed in aluminum cages in a well-ventilated room at ambient temperature (25 $27^{\circ} \mathrm{C}$ ) and natural light/darkness cycle. The rats were acclimatized for 2 weeks and the experimental protocol was approved by the Michael Okpara University of Agriculture, animal ethical committee.

\section{Feed Formulation}

The hydromethanol extract of $H$. annuus was incorporated in the feed at the rate of $2.5,5$ and $10 \mathrm{mg}$ @ 2017 Lifescience Global 
per $10 \mathrm{~g}$ feed. The rate of incorporation was based on the percentage yield of the extract and doses used in previous studies [4]. Briefly, 500, 1000 and $2000 \mathrm{mg}$ of the extract were weighed and dissolved in 2 litre of water each and later mixed with $2 \mathrm{~kg}$ of feed respectively. The resulting moist feed mixture was manually pelleted with the aid of the barrel of $5 \mathrm{ml}$ syringe. The pellets were dried under mild sunlight for 2 days in harmattan condition. The pelleted feeds were used within 2 weeks to avoid mold growth.

\section{Experimental Design}

The rats were randomly assigned to $4(A-D)$ groups of 14 rats each and treated as follow: group $A$ rats received standard pelleted feed while groups $B-D$ received feed incorporated with HLEHA at 2.5, 5 and $10 \mathrm{mg} / 10 \mathrm{~g}$ feed, respectively. They were fed $10 \%$ of their body weight daily for 90 consecutive days. They finished their feed each day and a deep feeding troughs were used to avoid feed wastage. On weekly bases, the rats were weighed and feeding was adjusted to accommodate the weight change. The hematological profiles of the rats were determined on day 30,60 and 90 of treatment. Four animals were randomly selected from each group at the timed interval and blood samples were collected from the retroorbital venous plexus with the aid of heparinized capillary tube into ethylenediaminetetraacetic acid (EDTA) bottle. The parameters were determined within $24 \mathrm{~h}$ of blood sample collection.
The method of Dacie and Lewis [12] was employed in red blood cell (RBC) count; hematocrit method [13] was used in packed cell volume (PCV) estimation while hemoglobin (HB) concentration was estimated with cyanomethemoglobin method using Drabkin's reagent [13]. The mean corpuscular volume (MCV), mean corpuscular hemoglobin $(\mathrm{MCH})$ and mean corpuscular hemoglobin concentration $(\mathrm{MCHC})$ was calculated as described by [14].

\section{Data Analysis}

The data were analyzed using one-way analysis of variance (ANOVA), variant means were separated least significant difference (LSD) and significance was accepted at $p<0.05$ with statistical package for social sciences (SPSS) version 21.0

\section{RESULTS}

Generally there was no significant ( $p>0.05)$ change in the value of all the parameters determined on day 30 and 60 except for $\mathrm{MCHC}$ on day 30 . There was no significant $(p>0.05)$ difference in the RBC values of the treatment groups (Table 1). At day 90, the PCV of Groups C and D were significantly $(p<0.05)$ lower than the value of group $A$ (Table 2). The $\mathrm{Hb}$ concentration of HLEHA -treated groups were significantly $(p<0.05)$ reduced compared to the rats that received standard feed on day 90 (Table 3). The MCV of group B was significantly $(p<0.05)$ lower while

\section{Table 1: Effect of HLEHA on RBC in Normal Rats}

\begin{tabular}{|c|c|c|c|c|}
\hline \multirow{2}{*}{ Group } & \multirow{2}{*}{ Treatment } & \multicolumn{3}{|c|}{ Mean total RBC count $\left(\times 10^{6} / \mu \mathrm{L}\right) \pm$ SEM } \\
\hline & & Day 30 & Day 60 & Day 90 \\
\hline A & Standard feed & $9.49 \pm 0.67$ & $8.75 \pm 0.22$ & $8.79 \pm 0.36$ \\
\hline B & HLEHA $2.5 \mathrm{mg} / 10 \mathrm{~g}$ feed & $9.68 \pm 0.27$ & $9.45 \pm 0.36$ & $9.74 \pm 0.40$ \\
\hline $\mathrm{C}$ & HLEHA $5 \mathrm{mg} / 10 \mathrm{~g}$ feed & $8.95 \pm 0.36$ & $8.43 \pm 0.21$ & $9.00 \pm 0.47$ \\
\hline $\mathrm{D}$ & HLEHA $10 \mathrm{mg} / 10 \mathrm{~g}$ feed & $8.74 \pm 0.37$ & $8.75 \pm 0.21$ & $8.51 \pm 0.47$ \\
\hline
\end{tabular}

$\mathrm{P}>0.05$ when compared to standard feed group HLEHA $=$ hydromethanol leaf extract of $H$. annuus; SEM = standard error of mean; RBC = Red blood cell.

Table 2: Effect of HLEHA on PCV in Normal Rats

\begin{tabular}{|c|c|c|c|c|}
\hline \multirow{2}{*}{ Group } & \multirow{2}{*}{ Treatment } & \multicolumn{3}{|c|}{ Mean PCV (\%) \pm SEM } \\
\cline { 2 - 5 } & & Day 30 & Day 60 & $45.38 \pm 0.85$ \\
\hline \hline A & Standard feed & $47.00 \pm 1.90$ & $44.38 \pm 1.95$ & $43.50 \pm 1.04$ \\
\hline B & HLEHA $2.5 \mathrm{mg} / 10 \mathrm{~g}$ feed & $47.63 \pm 0.43$ & $45.00 \pm 1.47$ & $42.00 \pm 1.29^{*}$ \\
\hline C & HLEHA $5 \mathrm{mg} / 10 \mathrm{~g}$ feed & $44.88 \pm 0.43$ & $44.00 \pm 1.08$ & $41.63 \pm 0.99^{*}$ \\
\hline D & HLEHA $10 \mathrm{mg} / 10 \mathrm{~g}$ feed & $44.25 \pm 1.69$ & $44.50 \pm 1.44$ & 90 \\
\hline
\end{tabular}

${ }^{*} \mathrm{p}<0.05$ compared to standard feed group; HLEHA = hydromethanol leaf extract of $H$. annuus; PCV = packed cell volume; SEM = standard error of mean. 
group $C$ and $D$ were not significant $(p>0.05)$ compared to group A on day 90 (Table 4). Also, on day 90, $\mathrm{MCH}$ of groups $\mathrm{B}$ and $\mathrm{C}$ were decreases significantly $(p<0.05)$ compared to group A (Table 5$)$. The MCHC of group D was significantly higher $(p<$ $0.05)$ compared to group $A$ on day 30 while the was no significant $(p>0.05)$ difference in the various treatment groups on days 60 and 90 (Table 6).

\section{Table 3: Effect of HLEHA on HB in Normal Rats}

\begin{tabular}{|c|c|c|c|c|}
\hline \multirow{2}{*}{ Group } & \multirow{2}{*}{ Treatment } & \multicolumn{3}{|c|}{ Mean HB (g/dl) \pm SEM } \\
\cline { 2 - 5 } & & Day 30 & Day 60 & $16.08 \pm 0.34$ \\
\hline \hline A & Standard feed & $14.49 \pm 0.55$ & $14.87 \pm 0.36$ & $14.72 \pm 0.28^{*}$ \\
\hline B & HLEHA $2.5 \mathrm{mg} / 10 \mathrm{~g}$ feed & $14.29 \pm 0.46$ & $15.35 \pm 0.27$ & $14.60 \pm 0.65^{*}$ \\
\hline C & HLEHA $5 \mathrm{mg} / 10 \mathrm{~g}$ feed & $14.34 \pm 0.16$ & $14.17 \pm 0.30$ & $14.84 \pm 0.39^{*}$ \\
\hline D & HLEHA $10 \mathrm{mg} / 10 \mathrm{~g}$ feed & $14.70 \pm 0.57$ & $15.25 \pm 0.22$ & 1 \\
\hline
\end{tabular}

${ }^{*} p<0.05$ compared to standard feed group; HLEHA = hydromethanol leaf extract of $H$. annuus; HB = hemoglobin; SEM = standard error of mean.

Table 4: Effect of HLEHA on MCV in Normal Rats

\begin{tabular}{|c|c|c|c|c|}
\hline \multirow{2}{*}{ Group } & \multirow{2}{*}{ Treatment } & \multicolumn{3}{|c|}{ Mean MCV (fl) \pm SEM } \\
\cline { 3 - 5 } & & Day $\mathbf{3 0}$ & Day $\mathbf{6 0}$ & $51.87 \pm 2.17$ \\
\hline \hline A & Standard feed & $50.00 \pm 2.58$ & $50.89 \pm 2.99$ & $44.90 \pm 2.07^{*}$ \\
\hline B & HLEHA $2.5 \mathrm{mg} / 10 \mathrm{~g} \mathrm{feed}$ & $49.33 \pm 1.35$ & $47.66 \pm 0.65$ & $46.84 \pm 1.23$ \\
\hline C & HLEHA $5 \mathrm{mg} / 10 \mathrm{~g}$ feed & $50.36 \pm 1.82$ & $52.35 \pm 2.07$ & $48.96 \pm 1.72$ \\
\hline D & HLEHA $10 \mathrm{mg} / 10 \mathrm{~g}$ feed & $50.77 \pm 1.69$ & $51.35 \pm 3.82$ & $\mathbf{2}$ \\
\hline
\end{tabular}

${ }^{*} \mathrm{p}<0.05$ compared to standard feed group; HLEHA = hydromethanol leaf extract of $H$. annuus; MCV = Mean corpuscular volume; SEM = standard error of mean.

Table 5: Effect of HLEHA on MCH in Normal Rats

\begin{tabular}{|c|c|c|c|c|}
\hline \multirow{2}{*}{ Group } & \multirow{2}{*}{ Treatment } & \multicolumn{3}{|c|}{ Mean MCH (pg) \pm SEM } \\
\cline { 3 - 5 } & & Day 30 & Day 60 & $18.37 \pm 0.63$ \\
\hline \hline A & Standard feed & $15.43 \pm 0.83$ & $17.05 \pm 0.78$ & $15.19 \pm 0.62^{*}$ \\
\hline B & HLEHA 2.5 mg/10 g feed & $14.83 \pm 0.82$ & $16.33 \pm 0.78$ & $16.30 \pm 0.72^{*}$ \\
\hline C & HLEHA $5 \mathrm{mg} / 10 \mathrm{~g}$ feed & $16.09 \pm 0.61$ & $16.87 \pm 0.71$ & $17.43 \pm 0.48$ \\
\hline D & HLEHA $10 \mathrm{mg} / 10 \mathrm{~g}$ feed & $16.93 \pm 0.99$ & $17.55 \pm 0.92$ & $\mathbf{2}$ \\
\hline
\end{tabular}

${ }^{*} \mathrm{p}<0.05$ compared to standard feed group; HLEHA = hydromethanol leaf extract of $H$. annuus; MCH = Mean corpuscular hemoglobin; SEM = standard error of mean.

Table 6: Effect of HLEHA on MCHC in Normal Rats

\begin{tabular}{|c|c|c|c|c|}
\hline \multirow{2}{*}{ Group } & \multirow{2}{*}{ Treatment } & \multicolumn{3}{|c|}{ Mean MCHC (\%) \pm SEM } \\
\cline { 3 - 5 } & & Day 30 & Day 60 & $33.61 \pm 0.82$ \\
\hline \hline A & Standard feed & $30.85 \pm 0.11$ & $34.27 \pm 1.60$ & $35.35 \pm 1.56$ \\
\hline B & HLEHA 2.5 mg/10 g feed & $30.00 \pm 0.95$ & $32.22 \pm 0.39$ & $34.77 \pm 1.02$ \\
\hline C & HLEHA 5 mg/10 g feed & $31.95 \pm 0.24$ & $34.33 \pm 0.75$ & $35.71 \pm 1.37$ \\
\hline D & HLEHA 10 mg/10 g feed & $33.28 \pm 1.12^{*}$ & 0.46 \\
\hline
\end{tabular}

${ }^{*} p<0.05$ compared to standard feed group; HLEHA = hydromethanol leaf extract of $H$. annuus; SEM = standard error of mean; MCHC = Mean corpuscular hemoglobin concentration. 
treatment. On day 90, mild normocytic hypochromic anemia was recorded in the extract treated groups which could be attributed to the phytochemical constituents of $H$. annuus. Ndam et al. [15] reported that the physiological, biochemical and pharmacological activities of medicinal plants is related to their phytoconstituents. Helianthus annuus has been reported to contain terpenes, alkaloids, saponins and other phytoconstituents [16]. Some of the terpenes and saponins isolated from $H$. annuus leaves and oil include; D-limonene, a-pinene, menthol, sabinene, germacrene $D$, camphene, $\beta$-pinene, isobornyl acetate, a-terpineol etc [2]. Mendanha et al. [17], reported the in vitro hemolytic activity of terpenes; nerolidol, 1,8cineole, a-terpineol, pulegone, $\alpha$-limonene etc, against normal human erythrocyte. The hemolytic activities of saponins have been proposed by researchers [18]. The reported hemolytic activities of saponins and terpenes shorten the life span of erythrocyte and predispose the affected animal to hemolytic anemia [19]. The mild anemia recorded in this study may be due to the low dose of $\mathrm{H}$. annuus that was used in the study. High dose may cause a more severe anemia even within shorter period [20]. The absence of significant difference in the red blood cell count may be due to regenerative response of the erythropoeitic tissue [14].

This study suggests that the chronic use of $H$. annuus leaf for up to 90 days in rat may lead to hemolytic anemia.

\section{ACKNOWLEDGEMENT}

The authors are grateful to Mr. A. O. Ozioko, a taxonomist with Bioresource Development and Conservation programme (BDCP) Enugu state, Nigeria for identification of the plant sample. The authors are also grateful to the management of Department of Veterinary Physiology, Pharmacology, Biochemistry and Animal Health and Production, Michael Okpara University of Agriculture, Umudike, Nigeria, for granting us access to the laboratory facilities for this work.

\section{DECLARATION OF CONFLICT OF INTEREST}

The authors declare no conflict of interest.

\section{FUNDING}

There was no external funding for this project.

\section{REFERENCE}

[1] Lentz DL, Pohl MD, Alvarado JL, Tarighat S, Bye R. Sunflower (Helianthus annuus L.) as a pre-Columbian

domesticate in Mexico. Proc Natl Acad Sci 2008; 105: 6232-37.

https://doi.org/10.1073/pnas.0711760105

[2]

Ceccarini L, Macchia M, Flamini G, Cioni PL, Caponi C Morelli I. Essential oil composition of Helianthus annuus L. leaves and heads of two cultivated hybrids "Carlos" and "Florom 350". Ind Crops Prod 2004; 19: 13-17. https://doi.org/10.1016/S0926-6690(03)00076-1

[3] Ejebe DE, Siminialayi IM, Amadi CN, et al. Effects of ethanol extract of leaves of Helianthus annuus on the reproductive system of male wistar rats: Testicular histology, epididymal sperm properties and blood levels of reproductive hormones. Biomedical \& Pharmacology Journal 2008; 1(1): 65-78.

[4] Onoja SO, Anaga AO. Evaluation of the antidiabetic and antioxidant potentials of methanolic leaf extract of Helianthus annuus L. on alloxan-induced hyperglycemic rats. Comp Clin Pathol 2014; 23: 1565-73. https://doi.org/10.1007/s00580-013-1824-3

[5] Ejebe DE, Siminialayi IM, Emudainohwo JOT, Ofesi U Morka L. Analgesic and anti-inflammatory activities of the ethanol extract of the leaves of Helianthus annuus in wistar rats. Asian Pac J Trop Med 2010; 3: 341-7. https://doi.org/10.1016/S1995-7645(10)60083-1

[6] Subashini R, Rakshitha SU. Phytochemical screening, antimicrobial activity and in vitro antioxidant investigation of methanolic extract of seeds from Helianthus annuus $\mathrm{L}$. Chem Sci Rev and Lett 2012; 1(1): 30-4.

[7] Fisk ID, R Linforth R, Trophardy G, Gray D. Entrapment of a volatile lipophilic aroma compound (D-limonene) in spray dried water-washed oil bodies naturally derived from sunflower seeds (Helianthus annus). Food Res Int 2013; 54: 861-6.

https://doi.org/10.1016/j.foodres.2013.08.024

[8] Ejebe DE , Siminialayi IM, Emudainohwo JOT , Kagbo HD Amadi P. Effects of ethanol extract of leaves of Helianthus annus on the fecundity of Wistar rats. Asian Pac J Trop Med 2010; 3: 435-8.

https://doi.org/10.1016/S1995-7645(10)60104-6

[9] Dwivedi A, Sharma GN, Kaushik AY. Evaluation of Helianthus annuus L. leaves extract for antidiarrheal and antihistaminic activity. Int J Res Ayurveda Pharm 2015; 6(1): 118-24.

https://doi.org/10.7897/2277-4343.06125

[10] Khan NI, Shinge JS, Naikwade NS. Antilithiatic effect of helianthus annuus linn. leaf extract in ethylene glycol and ammonium chloride induced nephrolithiasis. Int $\mathrm{J}$ Pharm Pharm Sci 2010; 2(suppl 4): 180-184.

[11] Baumann E, Stoya G, Völkner A, Richter W, Lemke C, Linss $W$. Hemolysis of human erythrocytes with saponin affects the membrane structure. Acta Histochem 2000; 102: 21-35. https://doi.org/10.1078/0065-1281-00534

[12] Dacie JV, Lewis SM. Practical heamatology. 7th ed. Edinburgh: ELBS with Churchill Livingstone 1991

[13] Alexander RR, Grifiths JM. Basic biochemical methods. 2nd ed. New York: Wiley-Liss 1993.

[14] Brar RS, Sandhu HS, Singh A. Veterinary clinical diagnosis by laboratory methods. New Delhi: Kalyani Publishers 2000; pp. 50.

[15] Ndam LM, Mih AM, Fongod AGN, et al. Phytochemical screening of the bioactive compounds in twenty (20) Cameroonian medicinal plants. Int J Curr Microbiol App Sci 2014; 3: 768-78.

[16] Ibrahim TA, Ajongbolo KF, Aladekoyi G. "Phytochemical screening and antimicrobial activity of crude extracts of Basella alba and Helianthus annuus on selected food pathogens. Research \& Reviews: Journal of Microbiology and Biotechnology 2014; 3(2): 27-31.

[17] Mendanha SA, Moura SS, Anjos JLV, Valadares MC, Alonso A. Toxicity of terpenes on fibroblast cells compared to their 
hemolytic potential and increase in erythrocyte membrane

fluidity. Toxicol In Vitro 2013; 27: 323-9.

https://doi.org/10.1016/j.tiv.2012.08.022

[18] Sofowora EA. Medicinal plants and traditional medicine in Africa. 3rd ed. Nigeria: Spectrum books Ltd.; 2008.
[19] Liu J, Goyer RA, Waalkes MP. Toxic effects of metals. In: Klaassen CD, editor. Casarett \& Doull's Toxicology: The Basic Science of Poisons. New York: McGraw-Hill 2008.

[20] Braide VB and Anika SM. Environmental toxicology. Nigeria: SNAAP press Ltd 2007. 